\title{
Tourism as a catalyst for poverty
}

\begin{abstract}
The Latin American economies have implemented structural changes since the second half of the 20th century characterized by widespread economic crises. In this sense, the neoliberal capitalist mode of production prevailed in the region in response to the suggestions of international organizations. The tourist activity as axis of accumulation and deterioration represents for Mexico the third source of economic income, since it generates $8.6 \%$ of the Gross Domestic Product (GDP) at national level and Quintana Roo contributes with $43 \%$ of the captured foreign currency. However, the data indicate high levels of poverty in the state, despite the importance of the tourism sector for the state and national economy, where the entity received almost $32 \%$ of international tourism during 2016. As a strategy to combat poverty, in 2012, the labor legislation was reformed, the changes legalized the practice identified as labor flexibilization, which leads to job insecurity.
\end{abstract}

Keywords: Tourism, poverty, employment precariousness, Mexico
Volume 3 Issue 6 - 2019

\author{
Alejandro Palafox-Muñoz \\ Universidad de Quintana Roo, Mexico
}

Correspondence: Alejandro Palafox-Muñoz, Universidad de Quintana Roo, Mexico,

Email alejandro.palafox.muno@gmail.com,palafo@uqroo.edu.mx

Received: November 08, 2019 | Published: December 10,

2019

\section{Introduction}

The concept of sustainable development deals with three important aspects: a) economic; b) social and; c) environmental; however, from the approach grounded in the economical rationality of the capitalist production mode, where the market are those regulating the work of economic and social activities, an incongruity occurs in their interests, since on the one hand, sustainability seeks to make a measured use of supplies for life; and on the other hand, mass production and immoderate consumption is privileged.

As a consequence, poverty has increased over time, as well as the inequalities of the system itself. In this sense, the narrow circumstances that stimulate the precariousness are often eradicated through labor, however, employment conditions have been deteriorating as the capitalist production mode has been upgrading. According to the Federal Labor Law, with the income generated by labor, workers have their human dignity respected, have access to social security and receive a profitable salary.

Official data reveals that tourism is considered an economic activity which generates a significant foreign currency earnings and employment, so that its exports are measured at 1.4 trillion US dollars. ${ }^{2}$ For the Mexican case, $4.6 \%$ of the jobs are linked to tourism, having a growth of $5.5 \%$ for the second quarter. ${ }^{3}$ Regarding the economic revenues by the arrival of tourists, SECTUR ${ }^{4}$ reported that 17,500 million US dollars were received during that year, and Quintana Roo contributes with $49.4 \%$ of the economic benefits of this concept into the country.

Notwithstanding the economic results, poverty is a constant in the country, with high rates in tourist areas; as a result of the increasing prices of goods and services, and the value of land in addition to the deterioration of labor conditions. In this sense, despite the contribution of Quintana Roo to the domestic economy, the number of poor people has increased on a general level and at the State's commitment to eradicate poverty, in 2000 Mexico had $11.3 \%$ of its population living in extreme poverty which decreased to $9.5 \%$ by 2014 , but the multidimensional poverty has had an increase.
In this sense, in the state of Quintana Roo, figures are similar since five municipalities of the state are in a situation of poverty that is $20.9 \%$ of the total population of the state, however, coastal municipalities with close relationship to the tourist activity and therefore greater number of population are in poverty situation $(88.3 \%)$, that is to say 342,340 people in the municipalities of Benito Juárez, Solidaridad and Othón P. Blanco. However, in the entire entity there are 827,200 people without access to social security. ${ }^{6}$ Despite being a region driven by tourism and economically dependent on it, the guidelines for the precariousness of life are reflected in the number of the employed population without access to social security, a figure that reached 370,100 inhabitants in 2012.

Figures show that there is no meeting point between a neoliberal tourism policy and results in the social sphere, although the interest of the State is in the economic indicators, the repercussions are reflected in the local communities, their inhabitants and the living conditions of them.

\section{Reforms that promote poverty}

A year before the end of the Second World War began the planning of the structural adjustments that the economy required with the purpose to avoid the lag in developing countries and regain Europe from war conflict. ${ }^{7}$ The response to monetary and financial issues that would be presented by the European reconstruction, was the creation of the World Bank (WB) and International Monetary Fund (IMF), the purpose of the first one was to make loans for restoring the States affected by the conflict and promote development of underdeveloped countries through the financing and economic assistance to those projects with development initiatives $;{ }^{8}$ the aim of the second one was to "establish the rules of the international monetary system, financial attention to member countries and be an advisory body to governments" (Idem: 79).

Latin American countries had a remarkable growth during the years of 1950 and 1980, this increase was characterized by the facilities of financing and the increase in exports. Given the outlook for 1960 and 1970, with these results it was intended to create a Latin 
American common market, but then the strategies were oriented to regional development, due to the characteristics that were presented, such as: a) protectionist policies; and b) constitution of monopolistic and oligopolistic structures. ${ }^{9}$ Therefore, the state should stimulate investment and direct productive activities, in order to compete in the international market.

In this way in 1989 through the Washington Consensus an "open, stable and liberalized economic model ... whose economic policy reforms are based on a logic of market characterized by openness and economic discipline" is crystallized. ${ }^{7}$ Therefore, to Latin America the opening consisted of allowing and facilitating international trade to boost growth through a neoclassical economic model and a neoliberal ideology and policies; and for that, the role of the state in economic activities should be reduced, since "it makes it difficult for the private sector to generate growth". ${ }^{10}$

The Washington Consensus reaffirms the provisions of the Bretton Woods reached agreements of 1944, which suggest that Latin American countries should provide greater certainty to private property, weakening the government economy, to promote free the exchange rates and interest rates and to reduce or eliminate taxes that guarantee free trade; this way, the neoliberal and capitalist mode of production will strengthen and expand its hegemony over Latin America, taking advantage of their vulnerability by external indebtedness to overcome underdevelopment by the loans received for that purpose, in order to be added in the globalized world, which is governed as a space without borders to the capital and presence of foreign investment; the result is the development poles between elites and extreme poverty ${ }^{11}$ that is $1 \%$ of the population owns more wealth than the remaining $99 \%$.

In this sense, as part of the drive to poverty and inequality, in 2012, a reform of labor legislation was conducted resulting in the new Federal Labor Law (LFT), which includes modern concepts whose purpose is to legalize a number of common practices in the labor market that had been presented in order to function according to the neoliberal policies of labor flexibilization, i.e., seasonal work, reduced or extended labor days, outsourcing, recruitment simulation by professional service fees, among others,,$^{12}$ despite the contradiction in the Federal Labor Law when it constitutes the "rules of work tend to achieve balance between production factors and social justice, as well as promote worthy or decent work in all labor relations"; however, according to Quiñones and Rodriguez ${ }^{13}$ the change in the law loosened the measures that ensured stability, by transferring risk and liability to the worker.

Despite the results, the state continues to promote sustainable development with bias for economic growth, leaving aside the social wellness which is widening the deterioration and extension of the inequality breaches. Therefore, the official view that has been given to poverty depends on time and the current government, ${ }^{14}$ as well as economic processes in which the country participates as part of global phenomena that place people as an active part of the international scene.

The State has contributed to the strengthening of the capitalist mode of production through two structural changes that impact directly in the productive forces, the first one through the constitutional amendment of the ejido (Article 127) and the legalization of the strategies of employment precariousness and labor flexibilization through the reformation of the Federal Labor Law, thus rural communities lose their means of production by being privatized or expropriated, and are driven to add to the mass of productive forces in deteriorating conditions and marginalization, i.e., poverty.

The topic has been extensively studied and most definitions include two key concepts, the lack of "something" that is necessary to satisfy "some" need. ${ }^{15}$ One of the main inadequacies referenced herein, made for its ability to be measured, is the economic income and United Nations has valued it with an income of less than $\$ 1.9$ dollars a day, ${ }^{16}$ while Mexico sets the minimum line of welfare in 28.94 pesos. ${ }^{6}$

To measure the income poverty is simple but it is not enough to understand the causes of it, or where the opportunities to combat its effects lies, since two people with the same income does not necessarily have the same living conditions therefore is necessary to analyze the phenomenon with a wider perspective. In this regard, the academic literature captures different ways to evaluate poverty, such as: a) income; b) capabilities; c) integrated methods; and d) multidimensional poverty. ${ }^{17-21}$

\section{Tourism as strategy to promote poverty}

According to the information submitted by the CONEVAL ${ }^{6}$ in Mexico extreme poverty has decreased, which is linked to income. However, it is imperative to note that much of the reduction is due to the welfare government transfers, since these influence 2.3 percentage points, equivalent to 2.8 million people who have left the status of extreme poverty. But if the measurement by capabilities is used, the result of the last two quinquennial evaluations reveals that the number of people has increased by two million in the food and housing areas, i.e. they do not have a home and their income is insufficient to cover a basic basket.

In this sense, the United Nations Development Program ${ }^{22}$ confirms that fighting poverty is not yielding the expected results; therefore, as long as the economic model does not receive structural changes and continue under the current scheme, poverty will continue maintaining and increasing as well as the inequality in the country.

Given the aforementioned, the only way for people to get the income to satisfy their needs is through decent work, which the Federal Labor Law' defines as "that in which the worker's human dignity is fully respected; ... there is access to social security and a remunerative salary is perceived..."

The growth of poverty rates is not a coincidence, since almost all Latin American economies have experienced similar behavior in the past two decades, which can be explained through changes in the economic policies that countries of the region have promoted, through legislative changes that make the materialization of desired effects by the elites of international economic organisms possible. In this sense, the precarisation of the social groups' employment included in production means are immediately turned into new poor people, i.e., families in which one or two members work, but whose social and working conditions as well as family burdens condemn them to poverty. ${ }^{23}$

The strategy of employment precariousness comes from the demands of the implementation of neoliberalism during the Consensus of Washington, where the weakening and reduction of state intervention, the elimination of customs duty and the promotion of free trade, among others, were established; for the purpose of supporting the growth of developed economies. ${ }^{7}$ However, the 
capitalist production mode is characterized by the brewing crises and the modernization to change the problems that it causes. Thus, one of the main consequences of the crisis is unemployment and increasing poverty, ${ }^{24}$ in addition to the new role of the state as regulator of production relations and strengthening of the owners of the production means, and promoter of the privatization through the precariousness of the means of production and deterioration of the working conditions and labor force. ${ }^{25,26}$

\section{Conclusion}

The neoliberal capitalist mode of production has established the parameters for the State to grant facilities for the reproduction of capital, by promoting labor flexibilization and the subsequent employment precariousness; and the reform of the Federal Labor Law has facilitated actions aimed to employment precariousness; in this idea, tourism is just one example of how the capitalist production mode increases poverty.

In this sense, tourism as an economic activity promoted by international organizations (World Bank / International Monetary Fund) in developing States, whose territory requires financing for access infrastructure and services for the arrival of investment of international tourism groups and the creation of Local Groups whose Global Commodity Chains, monopolize markets.

Undoubtedly, the official speech on tourism about the generation of wealth and employment has been released and accepted by the academy and society, however, the negative effects of it are treated with restraint and censorship, because the stronger effect dwell on the productive forces, who see their life quality deteriorated as a result of the precariousness of work, as well as their relationship with the production means, and therefore its deterioration in the purchasing power.

\section{Acknowledgments}

None.

\section{Conflicts of interest}

The author declares no conflicts of interest.

\section{Funding}

None.

\section{References}

1. Cámara de Diputados. 2012. Ley Federal del Trabajo, Distrito Federal: Cámara de Diputados del H. Congreso de la Unión. 2016.

2. UNWTO. Exports from international tourism rise $4 \%$ in 2015. World Tourism Barometer, 14 (May): 1-6 Madrid: World Tourism Organization. 2016.

3. SECTUR. Resultados de la actividad turística. México 2016. Ciudad de México: Secretaría de Turismo. 2017.

4. SECTUR. Empleo turístico. Ciudad de México: Secretaria de Turismo. 2016.

5. SEDETUR. Indicadores turísticos 2016. Chetumal: Secretaria de Turismo del Estado de Quintana Roo. 2017.

6. CONEVAL. Medición de la pobreza en México y en las entidades federativas 2014, Distrito Federal: Consejo Nacional para la Evaluación de la Política de Desarrollo Social. 2015.
7. Martínez Rub, Ernesto Reyes. El Consenso de Washington: la instauración de las políticas neoliberales en América Latina. Politica y Cultura. 2012;(37):35-64.

8. Tamames Ramón, Begoña Huerta. Estructura económica mundial. Madrid: Alianza Editorial. 2014.

9. CEPAL. Aglomeraciones en torno a los recursos naturales en América Latina y el Caribe: politicas de articulación y articulación de políticas, Santiago: Comisión Económica para América Latina y el Caribe. 2005.

10. Kuczynski, Pedro y John Williamson. Después del Consenso de Washington. Relanzando el crecimiento y reformas en América Latina, Lima: Universidad Peruana de Ciencias Aplicadas - The Institute for International Economics. 2003.

11. OXFAM. Una economía al servicio del 1\%, Oxford: Oxfam International. 2016 ,

12. Rubí Felipe, Alejandro PM. El turismo como catalizador de pobreza en Cozumel, México, Tesis de Maestría en Gestión Sustentable del Turismo, Cozumel: Universidad de Quintana Roo. 2016.

13. Quiñones Carlos, Salvador Rodríguez. La reforma laboral, la precarización del trabajo y el principio de estabilidad en el empleo. Revista Latinoamericana de Derecho Social. 2015;(21):179-201.

14. Barajas Gabriela. Las políticas de administración de la pobreza en México: ayer y hoy. Foro Internacional. 2002;42(1):63-98.

15. Gutiérrez-Perez, Francisco, Diego Medina-Muñoz y Rita MedinaMuñoz. Turismo y alivio de la pobreza: una revisión de la literatura académica. Tourism \& Management Studies. 2014;10(2):104-115.

16. The World Bank. Development goals in an era of demographic change. Washington: The World Bank. 2016.

17. CONEVAL. Metodología para la medición multidimensional de la pobreza en México, Distrito Federal: Consejo Nacional para la Evaluación de la Política de Desarrollo Social. 2010.

18. Damián Araceli, Julio Boltvinik. Evolución y características de la pobreza en México. Comercio Exterior. 2003;53(6):519-531.

19. Feres Juan Carlos, Xavier Mancero. Enfoques para la medición de la pobreza. Breve revisión de la literatura. Santiago de Chile: Comisión Económica para América Latina y el Caribe. 2001.

20. Núñez José. Estado actual y nuevas aproximaciones a la medición de la pobreza. Estudios de economía aplicada. 2009;27(2):325-344.

21. Sutcliffe Bob. Desarrollo humano: una valoración crítica del concepto e índice. Cuadernos de Hegoa. 1993;1(11):1-65.

22. PNUD. Progreso multidimensional: bienestar más allá del ingreso. Nueva York: Programa de las Naciones Unidas para el Desarrollo. 2016.

23. Climent Víctor. La nueva pobreza en el mercado de trabajo. Inteligible Capital. 2015;11(2):270-283.

24. Suárez María, Héctor Adriani, Ariel Alvari, et al. Principales características de la precarización laboral en La Gran Plata. Periodo 2003-2004. $7^{\circ}$ Congreso Nacional de Estudios del Trabajo, Buenos Aires: Asociación Argentina de Especialistas en Estudios del Trabajo. 2004.

25. OIT. Hechos concretos sobre la seguridad social. Ginebra: Organización Internacional del Trabajo. 1991.

26. OIT. Seguridad social para la justicia social y una globalización equitativa, Ginebra: Organización Internacional del Trabajo. 2011. 